\title{
Correction to: Effect of Coatings and Coating Methods on Cluster Index in Iron Oxide Pellets for Direct Reduction Shaft Furnaces
}

\author{
JEAN PHILIPPE SANTOS GHERARDI DE ALENCAR (D, \\ VALDIRENE GONZAGA DE RESENDE (D), and WANDER LUIZ VASCONCELOS (1)
}

https://doi.org/10.1007/s11663-022-02456-y

(C) The Minerals, Metals \& Materials Society and ASM International 2022

\section{Correction to:}

Metallurgical and Materials Transactions B

https://doi.org/10.1007/s11663-021-02361-w

IN the original online version of this article there was an error in the last sentence on page 242 when citing the results of Ref. 16. The corrected sentence is as follows:

However, Wang et al. ${ }^{[16]}$ demonstrated another research where increasing hydrogen led to a higher sticking and they attributed this to the fact that the reduction diffusion rate of $\mathrm{H}_{2}$ was faster, resulting in more contacts of metallic iron phases on the surface of pellets.

The original article was corrected.

Publisher's Note Springer Nature remains neutral with regard to jurisdictional claims in published maps and institutional affiliations.

JEAN PHILIPPE SANTOS GHERARDI DE ALENCAR, and VALDIRENE GONZAGA DE RESENDE are with the Marketing Department, Vale S.A., Nova Lima 34006-270, Brazil. Contact e-mail: jeanpga@gmail.com WANDER LUIZ VASCONCELOS is with the Metallurgical Department, Federal University of Minas Gerais, Belo Horizonte 31270-901, Brazil.

The original article can be found online at https://doi.org/10.1007/ s11663-021-02361-w.

Article published online February 6, 2022. 